\title{
Balanced Development using Ontology-Based Tantra Framework
}

\author{
Shreekanth M. Prabhu*, K. N. Balasubramanya Murthy and Subramanyam Natarajan
}

PES University, 100 Feet Outer Ring Road, Bangalore - 560085, India; shreekanthprabhu@pes.edu

\begin{abstract}
The idea of Balanced Development is to ensure equitable distribution of necessities of life and creation of productive remunerative employment across society. Balanced development is a prerequisite for sustainable economic growth and shared prosperity. To facilitate this challenging task, we have proposed an Ontology-based Tantra Social Information Management Framework that can help set goals, design and evaluate interventions, define and monitor relevant metrics in an ongoing basis. Tantra Framework represents social information using ideas from Zachman Framework and concepts from Unified Foundational Ontology. Tantra Framework inter-operates with well-regarded models. Balanced Scorecard is used to define development objectives. Bartels' Theory of Separations is used to identify barriers to access, consumption and profitable participation. Theory of Change process is used to arrive at right intervention. Distributed Ledgers are proposed to handle Change Management. A Social Information Management Process is proposed to keep the framework populated, complete and current. Tantra Framework can lead to broader Digital Governance Framework with strong cognizance of Social dimension. The paper explains how Tantra Framework can be used to realize Economic Development in Indian context.
\end{abstract}

Keywords: Balanced Development, Balanced Scorecard, Ontology, Theory of Change, Zachman Framework

\section{Introduction}

Countries such as India and Pakistan after independence approached development 5-year plans the main thrust was on industrialization. However, in the last few decades, many countries have shifted their focus towards holistic development of all sectors, regions and people. To assess holistic development, the UN has adopted the Millennium Development Goals (MDG) Framework consisting of eight goals in September 2000. In 2015, UN replaced MDG Framework with Sustainable Development Goals (SDG) framework consisting of 17 goals, to be used for the period 2015 to 2030 . These goals pertain to elimination of poverty and hunger, ensuring good health, quality education and gender equality, providing access to clean water and sanitation, affordable and clean energy, decent work and economic growth, etc

The notion of Balanced Development is proposed by Jehangir Khan in his paper (Khan, Faheem Jehangir, 2008) on Medium Term Development Framework (MTDF) for
Pakistan. He described the goal of balanced development as providing employment with income generation, housing for all and good governance to rural, urban and less developed/ remote areas. He characterized Good Governance as key link between growth and reduction of poverty and inequality. Further, he listed the following issues, which act as impediments to balanced development:

- Poor management of resources; disparities in the pace and level of development across provinces and across districts,

- Denial of basic needs of food, water and shelter to a substantial proportion of the population,

- Lack of sensitivity, transparency and accountability in many facets of the State machinery, particularly those that have an interface with the public,

- Marginalization, exclusion or even persecution of people on account of social, religious, ethnic or even gender affiliations,

- Lack of credibility - the gap between the intent and the actions - of some institutions in society, 
- Inadequate application of rules, evasion of taxes and failure in getting timely justice,

- Existence of a significant number of the voiceless poor with little opportunities for participating, and

- Deterioration of physical environment in the urban and rural areas.

To achieve good governance, we need a way to manage information related to Governance and Society in a comprehensive and holistic manner, so that Governments can make informed choices. To that end, we have proposed Ontology-based Tantra Framework captures information on People, Addresses and Locations, Assets and Attributes, Events, Processes and Objectives as well as relationships and relators.

Rest of the paper is organized as follows. Section 2, Frameworks and Models dwells on approaches to manage information. Section 3, elaborates the proposed Ontologybased Tantra Framework. Section 4 describes Application of Tantra Framework for Balanced Development. Section 5, Discussions describes the proposed Social Information Management Process and how Tantra Framework can be evolved to a broader Digital Governance Framework. Section 6, Conclusions, concludes the paper and outlines future research opportunities.

\section{Frameworks and Models}

\subsection{Defining Framework}

From a researcher's view-point, "a framework is a way of representing the empirical relations between every aspect of inquiry. It describes the general direction and the constraints of the theory or research. It is an organized structure of ideas, concepts, and other things that are involved. A well-developed framework should be coherent and serve as a communication tool to stakeholders".

\subsection{Zachman Framework}

Zachman Framework (Zachman, 2003) has rows and columns that can capture information in a holistic and comprehensive manner. Zachman Framework is illustrated in Table 1.

Here the columns are primary interrogatives of English Language - who, what, when, where, how and why. The rows represent the perspectives of Planner, Owner, Designer, Builder, Implementer and Operator respectively (Zachman, 2007). The purpose of rows is given below.

Table 1. Zachman framework

\begin{tabular}{|c|c|c|c|c|c|c|}
\hline & What & How & Where & Who & When & Why \\
\hline Contextual & $\begin{array}{l}\text { List of things } \\
\text { important to } \\
\text { business }\end{array}$ & $\begin{array}{l}\text { List of core } \\
\text { business } \\
\text { processes }\end{array}$ & $\begin{array}{l}\text { List of business } \\
\text { locations }\end{array}$ & $\begin{array}{l}\text { List of important } \\
\text { organizations }\end{array}$ & List of Events & $\begin{array}{l}\text { List of business } \\
\text { goals } \\
\text { Strategies }\end{array}$ \\
\hline Conceptual & $\begin{array}{l}\text { Conceptual } \\
\text { data / object } \\
\text { model }\end{array}$ & $\begin{array}{l}\text { Business Process } \\
\text { Model }\end{array}$ & $\begin{array}{l}\text { Business } \\
\text { Logistics System }\end{array}$ & $\begin{array}{l}\text { Work Flow } \\
\text { Model }\end{array}$ & Master Schedule & Business Plan \\
\hline Logical & $\begin{array}{l}\text { Logical Data } \\
\text { Model }\end{array}$ & $\begin{array}{l}\text { System } \\
\text { Architecture } \\
\text { Model }\end{array}$ & $\begin{array}{l}\text { Distributed } \\
\text { System } \\
\text { Architecture }\end{array}$ & $\begin{array}{l}\text { Human Interface } \\
\text { Architecture }\end{array}$ & $\begin{array}{l}\text { Processing } \\
\text { Structure }\end{array}$ & $\begin{array}{l}\text { Business Role } \\
\text { Model }\end{array}$ \\
\hline Physical & $\begin{array}{l}\text { Physical data/ } \\
\text { Class model }\end{array}$ & $\begin{array}{l}\text { Technology } \\
\text { Design Model }\end{array}$ & $\begin{array}{l}\text { Technology } \\
\text { Architecture }\end{array}$ & $\begin{array}{l}\text { Presentation } \\
\text { Architecture }\end{array}$ & $\begin{array}{l}\text { Control } \\
\text { Structure }\end{array}$ & $\begin{array}{l}\text { Rule } \\
\text { Design }\end{array}$ \\
\hline Detailed & $\begin{array}{l}\text { Data } \\
\text { Definitions }\end{array}$ & Program & $\begin{array}{l}\text { Network } \\
\text { Architecture }\end{array}$ & $\begin{array}{l}\text { Security } \\
\text { Architecture }\end{array}$ & $\begin{array}{l}\text { Timing } \\
\text { Definition }\end{array}$ & $\begin{array}{l}\text { Rule } \\
\text { Specification }\end{array}$ \\
\hline $\begin{array}{l}\text { Functioning } \\
\text { Enterprise }\end{array}$ & Usable Data & $\begin{array}{l}\text { Working } \\
\text { Function }\end{array}$ & Usable network & $\begin{array}{l}\text { Functioning } \\
\text { Organization }\end{array}$ & $\begin{array}{l}\text { Implemented } \\
\text { Schedule }\end{array}$ & $\begin{array}{l}\text { Working } \\
\text { Strategy }\end{array}$ \\
\hline
\end{tabular}


- The purpose of row 1 artifacts is to define the boundaries of the enterprise, which includes the scope of the enterprise,

- Row 2 artifacts' purpose is to conceptually define what the enterprise owners have in mind,

- Row 3 artifacts design how the concepts of the enterprise will be realized systematically,

- The purpose of row 4 is to define the enterprise implementation keeping in mind the technology constraints, and

- Row 5 artifacts' purpose is to specify the implementations to specific technology products being used for the implementation.

\subsection{Unified Foundational Ontology (UFO)}

Another important topic when building a generic framework is Ontology. UFO Ontology defines Universals which map to concepts that get instantiated as Individuals. The individuals can be endurants or perdurants (events). There are relationships which are more like attributes and other type of relationships which need an intermediary called relator. In (Santos Jr, Paulo et.al, 2013) ARIS method is developed that makes use of UFO ontology and applies it to organizations. The UFO constructs are explained in Table $2 \& 3$.

Table 2. UFO concepts

\begin{tabular}{|c|c|c|c|c|c|c|c|c|c|}
\hline Level & 1 & 2 & 3 & 4 & 4 & 5 & 5 & 6 & 7 \\
\hline Concept & $\begin{array}{l}\text { Basic } \\
\text { Elements }\end{array}$ & Universals & Individuals & Endurants & Perdurants & Substantial & Moment & $\begin{array}{l}\text { Intrinsic } \\
\text { Moment }\end{array}$ & $\begin{array}{l}\text { Relational } \\
\text { Moment } \\
\text { (Relator) }\end{array}$ \\
\hline Description & $\begin{array}{l}\text { Universals or } \\
\text { Individuals }\end{array}$ & $\begin{array}{l}\text { Named } \\
\text { level in } \\
\text { Zachman }\end{array}$ & $\begin{array}{l}\text { Instantiate } \\
\text { Universals }\end{array}$ & $\begin{array}{l}\text { Type of } \\
\text { Individuals }\end{array}$ & $\begin{array}{l}\text { Events that } \\
\text { make up } \\
\text { processes }\end{array}$ & $\begin{array}{l}\text { Objects } \\
\text { that exist } \\
\text { independently }\end{array}$ & $\begin{array}{l}\text { Exist only } \\
\text { if bearer } \\
\text { exists }\end{array}$ & $\begin{array}{l}\text { Depend on } \\
\text { Single Entity }\end{array}$ & $\begin{array}{l}\text { Moments } \\
\text { depend on } \\
\text { other entities } \\
\text { in addition to } \\
\text { the bearer }\end{array}$ \\
\hline Examples & & People & & $\begin{array}{l}\text { House, } \\
\text { Person, } \\
\text { Moon, } \\
\text { Enterprise }\end{array}$ & $\begin{array}{l}\text { Business } \\
\text { processes, } \\
\text { Enrollment } \\
\text { processes }\end{array}$ & $\begin{array}{l}\text { Person, a } \\
\text { house, a planet, } \\
\text { and the rolling } \\
\text { stones }\end{array}$ & $\begin{array}{l}\text { John's } \\
\text { weight, } \\
\text { John and } \\
\text { Mary's } \\
\text { marriage }\end{array}$ & $\begin{array}{l}\text { Colour of } \\
\text { something } \\
\text { Temperature } \\
\text { of some } \\
\text { object }\end{array}$ & $\begin{array}{l}\text { Employment } \\
\text { with employer } \\
\text { Mary's } \\
\text { marriage with } \\
\text { John }\end{array}$ \\
\hline
\end{tabular}

Table 3. UFO relations

\begin{tabular}{|l|l|l|l|l|l|}
\hline Concept & $\begin{array}{l}\text { Independent } \\
\text { Intrinsic } \\
\text { Moments }\end{array}$ & $\begin{array}{l}\text { Dependent } \\
\text { Intrinsic } \\
\text { Moments }\end{array}$ & Formal Relation & $\begin{array}{l}\text { Material Relations / } \\
\text { Domain Relation }\end{array}$ & Relator \\
\hline Examples & $\begin{array}{l}\text { Size and colour } \\
\text { of an object }\end{array}$ & $\begin{array}{l}\text { Colour and } \\
\text { brightness of } \\
\text { an object }\end{array}$ & $\begin{array}{l}\text { Village belonging } \\
\text { to a District. Paul's } \\
\text { headache. }\end{array}$ & $\begin{array}{l}\text { Working at, being } \\
\text { enrolled at, and } \\
\text { being the husband } \\
\text { of. Medical } \\
\text { treatment to Paul }\end{array}$ & $\begin{array}{l}\text { An enrollment connects a } \\
\text { student with an educational } \\
\text { institution; A Government } \\
\text { Department/policy/process } \\
\text { connects a citizen with } \\
\text { benefit or privilege. }\end{array}$ \\
\hline
\end{tabular}

\subsection{Maes' Generic Information Management Framework}

Rik Maes (1999) proposed a generic framework for investigating and inter-relating the different components of information management. The framework is represented in Figure 1. Here, the rightmost column represents technology such as systems and databases and leftmost column represents application that captures the business expertise the middle column represents the interpretation of information, communication and knowledge (sharing) processes. Maes then stressed on the importance of middle column of handling information and communication, by quoting several previous studies. Here a business in looked systemically. 


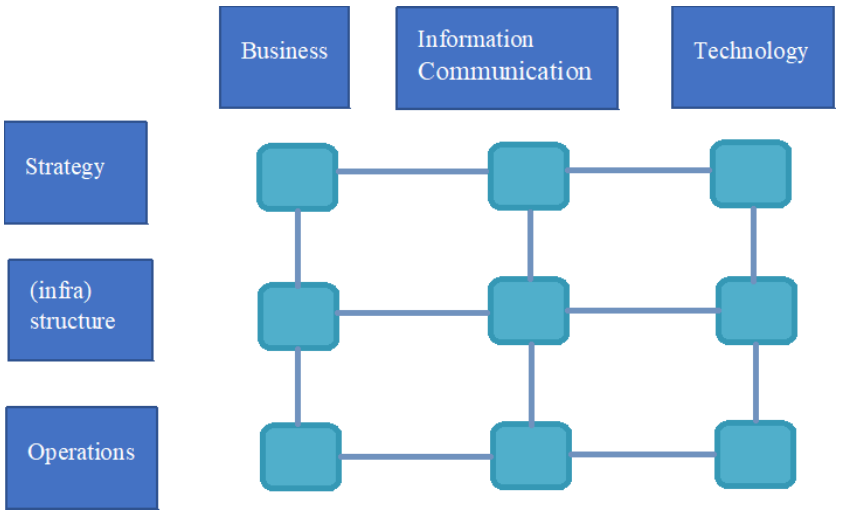

Figure 1. The generic framework for information management.

\subsection{Balanced Scorecard}

A commercial enterprise can be managed and led using a balanced score-card framework (Kaplan, 2010). It is possible to apply the same approach to Government. The same five perspectives that apply to an enterprise may be applicable, namely

- Financial,

- Customer (Citizen/Community/Business),

- Internal Business (Process of Governance),

- $\quad$ Learning and Growth (Innovation and strategy), and

- $\quad$ Ethical.

The score card can be created and tracked in terms of Strategies, Objectives and metrics in line with mission and vision of an organization as illustrated in Figure 2.

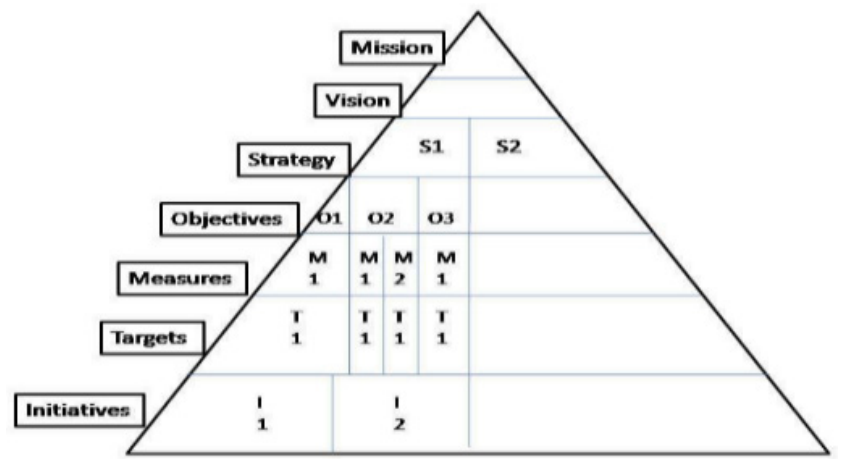

Figure 2. Balanced scorecard pyramid (Kaplan and Norton 1996).

\subsection{Theory of Change}

Kurt Lewin famously said, "There is nothing more practical than good theory". Theory of Change (Weiss,
1995) is essentially a comprehensive description and illustration of how and why a desired change is expected to happen in a specific context. It does this by first identifying the desired long-term goals and then works back from these to identify all the conditions (outcomes) that must be in place (and how these related to one another causally) for the goals to occur. This leads to better planning, evaluation and monitoring of the initiatives.

\subsection{Theory of Separations}

Major objective of Governance is economic development. Here we would like to leverage ideas from Bartels theory of market separations (Bartels, 1968). Bartels identified four different separations that come in the way of marketdevelopment.

- Spatial separation or the physical distances between producers and consumers,

- Temporal separation or the time difference between production and consumption,

- Informational separation or the information asymmetry between producers and consumers related to products and market conditions, and

- Financial separation or the lack of consumers' purchasing power when they are willingness to fulfill their needs".

Certain researchers have added Knowledge/Capability based separation as the 5th separation (Tarafdar \& Singh, 2011).

\section{Ontology-Based Tantra Framework}

Governance Systems can be considered as complex systems where large number of people and entities interact. Connectedness of a complex system comprises of two facets: one is at the level of structure of linkages, and another is at the level of behaviour. Every action by an actor will be responded by other actors. As such, a wellintentioned Government program in many cases results in unintended outcomes.

"Traditional Economic analysis looks at society either with Macro or Micro perspective. In reality much of the economic life takes place in the continuum 
between the two. Sociology traditionally looks at smaller groups where data collection and analysis can be managed, as well as behaviour can be studied. But today social interactions span all over the globe in a digital and virtual manner. Today's technologies make it easy to manage large amounts of data; (iii) Today's computer platforms are largely social where people provide feedback, share knowledge, express opinions, provide suggestions for policy and get influenced by their communities. The social dimension has overtaken the technology dimension" (Easley \& Kleinberg, 2010). Hence, we need a multi-pronged approach that synergizes these perspectives. To meet this challenging task, we propose Ontology-based Tantra Framework. Tantra Framework models the social information as a multi-modal social network.

The name Tantra Framework is chosen to reflect enormous connectivity of information through the framework. Etymologically in Sanskrit "tantram", literally means "loom, warp" hence, figuratively, "groundwork, system, doctrine".

Tantra Framework extends Zachman by adding two additional columns namely relators and relationships. The relationship column is used to represent any relationship which may correspond to a data-map or structured map, between framework columns. A relator column is added to represent any entity/concept that is integral part of any relationship. Yet another column namely separations is used to represent lack of relationship or the level of difficulty to access the relationship.

The aspects of Tantra Framework can be used to expresses social information as follows. In addition, under "Who" aspect, we can model communities, categories of people as well as businesses and institutions. The Table 4 gives the view of Tantra Framework.

- People (Who),

- Places/Addresses/Locations/Zones (Where),

- Assets/Attributes (What),

- Events (When),

- Processes (for enrolment, intervention) (How),

- Metrics to measure development (Why),

- Relators (enable relationships),

- Relationships (between aspects), and

- Separations (express lack of or difficulty of establishing a relationship).

Tantra Framework as defined above can be converted into a normative framework by interoperating with models that can help achieve Good Governance. Here Goals can be set using Balanced Scorecard Framework and interventions can be modeled and managed through Theory of Change Framework. The Separations can be expressed by drawing on Bartels' Theory of Separations (Figure 3).

Table 4. Tantra framework

\begin{tabular}{|l|l|l|l|l|l|l|l|l|l|}
\hline \multirow{2}{*}{\multicolumn{1}{|c|}{ Perspectives }} & \multicolumn{9}{|c|}{ Aspects } \\
\cline { 2 - 9 } & Who & Where & What & When & How & Why & Relationships & Relators & Separations \\
\hline $\begin{array}{l}\text { Contextual (Named } \\
\text { and Scoped) }\end{array}$ & & & & & & & & & \\
\hline $\begin{array}{l}\text { Conceptual } \\
\text { (Defined) }\end{array}$ & & & & & & & & & \\
\hline $\begin{array}{l}\text { Logically } \\
\text { Designed }\end{array}$ & & & & & & & & & \\
\hline $\begin{array}{l}\text { Physically } \\
\text { Configured } \\
\text { (Schema) }\end{array}$ & & & & & & & & & \\
\hline $\begin{array}{l}\text { Detailed/ } \\
\text { Instantiated) }\end{array}$ & & & & & & & & & \\
\hline
\end{tabular}




\begin{tabular}{|l|}
\hline Goals (Balanced Scorecard) \\
\hline Interventions (Theory of Change) \\
\hline $\begin{array}{l}\text { Networks (Structured Maps) and } \\
\text { Separations (Disconnects) }\end{array}$ \\
\hline Relations (Aspects) \\
\hline Domains/Roles/Entity Sets (Instances) \\
\hline Discrete Information Space \\
\hline
\end{tabular}

Figure 3. Tantra framework with interoperating models.

In Tantra Framework as in Zachman Framework every aspect goes through the process of reification. Table 5 describes how People Domain is reified. Table 6 describes how the Addresses are reified. The addresses in turn are located in Zones or Geographic contexts which are uniquely identified. Table 7 covers asset perspectives. The assets belong to "what" Aspect. In the same manner Loans, Taxed and duties paid/payable can be modeled in the Tantra Framework under "What" aspect. This can help get a complete financial profile of borrowers. Table 8 covers the perspectives pertaining to Objectives. Table 9 covers the reification of relationships and relators and Table 10 covers separations with access to Formal Credit. Similarly, events that occur during life-time of a person can be reified and given a unique ID. These include birth, attaining maturity, migration, enrollment, emigration, immigration and death The processes can similarly be covered.

Table 5. Reification of people domain

\begin{tabular}{|l|l|l|l|l|l|}
\hline \multicolumn{1}{|c|}{ Perspective } & \multicolumn{1}{|c|}{ All people } & \multicolumn{1}{c|}{ Citizens } & \multicolumn{1}{c|}{ Residents } & \multicolumn{1}{c|}{ Resident Aliens } & \multicolumn{1}{c|}{$\begin{array}{l}\text { Resident } \\
\text { Citizens }\end{array}$} \\
\hline $\begin{array}{l}\text { Named (Identified } \\
\text { \& Contextua-lized) }\end{array}$ & $\begin{array}{l}\text { All the people } \\
\text { known and to } \\
\text { be known to the } \\
\text { framework. }\end{array}$ & $\begin{array}{l}\text { People who t are } \\
\text { citizens }\end{array}$ & $\begin{array}{l}\text { People who are } \\
\text { residents }\end{array}$ & $\begin{array}{l}\text { People who are } \\
\text { resident but alien }\end{array}$ & $\begin{array}{l}\text { Resident } \\
\text { Citizens }\end{array}$ \\
\hline $\begin{array}{l}\text { Defined } \\
\text { (Conceptually } \\
\text { Structured) }\end{array}$ & $\begin{array}{l}\text { What makes one } \\
\text { a member of this } \\
\text { domain/role }\end{array}$ & $\begin{array}{l}\text { What makes one } \\
\text { a member of this } \\
\text { domain/ role }\end{array}$ & $\begin{array}{l}\text { What makes one } \\
\text { a member of this } \\
\text { domain/role }\end{array}$ & $\begin{array}{l}\text { What makes one } \\
\text { a member of this } \\
\text { domain/role }\end{array}$ & $\begin{array}{l}\text { What makes one } \\
\text { a member of this } \\
\text { domain/ role }\end{array}$ \\
\hline Logically Designed & $\begin{array}{l}\text { Related attributes } \\
\text { that map to other } \\
\text { aspects. }\end{array}$ & $\begin{array}{l}\text { Related attributes } \\
\text { that map to other } \\
\text { aspects }\end{array}$ & $\begin{array}{l}\text { Related attributes } \\
\text { that map to other } \\
\text { aspects. }\end{array}$ & $\begin{array}{l}\text { Related attributes } \\
\text { that map to other } \\
\text { aspects. }\end{array}$ & $\begin{array}{l}\text { Related } \\
\text { attributes that } \\
\text { map to other } \\
\text { aspects. }\end{array}$ \\
\hline Configured & $\begin{array}{l}\text { Representation in } \\
\text { Graph database } \\
\text { as nodes and } \\
\text { edges. }\end{array}$ & $\begin{array}{l}\text { Representation in } \\
\text { Graph database } \\
\text { as nodes and } \\
\text { edges. }\end{array}$ & $\begin{array}{l}\text { Representation in } \\
\text { Graph database as } \\
\text { nodes and edges. }\end{array}$ & $\begin{array}{l}\text { Representation in } \\
\text { Graph database as } \\
\text { nodes and edges. }\end{array}$ & $\begin{array}{l}\text { Representation } \\
\text { in Graph } \\
\text { database as } \\
\text { nodes and edges. }\end{array}$ \\
\hline Instantiated & $\begin{array}{l}\text { Instantiate with } \\
\text { unique ID. }\end{array}$ & $\begin{array}{l}\text { Instantiate with } \\
\text { unique ID. }\end{array}$ & $\begin{array}{l}\text { Instantiate with } \\
\text { unique ID. }\end{array}$ & $\begin{array}{l}\text { Instantiate with } \\
\text { unique ID. }\end{array}$ & $\begin{array}{l}\text { Instantiate with } \\
\text { unique ID. }\end{array}$ \\
\hline
\end{tabular}

Table 6. Reification of addresses

\begin{tabular}{|l|l|l|l|l|l|}
\hline & Residential address & $\begin{array}{l}\text { General Address/ } \\
\text { Location }\end{array}$ & $\begin{array}{l}\text { Commercial } \\
\text { Address }\end{array}$ & $\begin{array}{l}\text { Institutional } \\
\text { address }\end{array}$ & $\begin{array}{l}\text { Address for public/ } \\
\text { civic amenity }\end{array}$ \\
\hline Named (Identified) & $\begin{array}{l}\text { Idea named with } \\
\text { context }\end{array}$ & $\begin{array}{l}\text { Idea named with } \\
\text { context }\end{array}$ & $\begin{array}{l}\text { Idea named with } \\
\text { context }\end{array}$ & $\begin{array}{l}\text { Idea named } \\
\text { with context }\end{array}$ & $\begin{array}{l}\text { Idea named with } \\
\text { context }\end{array}$ \\
\hline $\begin{array}{l}\text { Defined } \\
\text { (Conceptually } \\
\text { Structured) }\end{array}$ & $\begin{array}{l}\text { Concept of Residential } \\
\text { address. Membership } \\
\text { criteria, entry and exit }\end{array}$ & $\begin{array}{l}\text { Concept of Generic } \\
\text { address or location }\end{array}$ & $\begin{array}{l}\text { Concept of } \\
\text { Commercial } \\
\text { address. Entry } \\
\text { and exit criteria. }\end{array}$ & $\begin{array}{l}\text { Concept of } \\
\text { Institutional } \\
\text { Address } \\
\text { Membership } \\
\text { Criteria }\end{array}$ & $\begin{array}{l}\text { Concept of } \\
\text { utility/amenity - } \\
\text { playground, park. }\end{array}$ \\
\hline
\end{tabular}




\begin{tabular}{|l|l|l|l|l|l|}
\hline Logically Designed & $\begin{array}{l}\text { Attributes of } \\
\text { Residential addresses }\end{array}$ & $\begin{array}{l}\text { Attributes of } \\
\text { Generic addresses }\end{array}$ & $\begin{array}{l}\text { Attributes of } \\
\text { commercial } \\
\text { addresses. }\end{array}$ & $\begin{array}{l}\text { Attributes of } \\
\text { Institutional } \\
\text { addresses }\end{array}$ & $\begin{array}{l}\text { Attributes of } \\
\text { amenities. }\end{array}$ \\
\hline Configured & $\begin{array}{l}\text { Schema for } \\
\text { Residential addresses }\end{array}$ & $\begin{array}{l}\text { Schema for storing } \\
\text { generic addresses }\end{array}$ & $\begin{array}{l}\text { Schema for } \\
\text { commercial } \\
\text { address }\end{array}$ & $\begin{array}{l}\text { Schema for } \\
\text { institutional } \\
\text { addresses }\end{array}$ & $\begin{array}{l}\text { Schema for storing } \\
\text { details about } \\
\text { address }\end{array}$ \\
\hline Instantiated & $\begin{array}{l}\text { Instantiate with } \\
\text { unique ID (Unique } \\
\text { ID+ Address ID) }\end{array}$ & $\begin{array}{l}\text { Instantiate with } \\
\text { Unique ID (GPS } \\
\text { IS?) }\end{array}$ & $\begin{array}{l}\text { Instantiate with } \\
\text { Unique ID }\end{array}$ & $\begin{array}{l}\text { Instantiate with } \\
\text { Unique ID }\end{array}$ & $\begin{array}{l}\text { Instantiate with } \\
\text { Unique ID }\end{array}$ \\
\hline
\end{tabular}

Table 7. Reification of assets

\begin{tabular}{|l|l|l|l|}
\hline \multicolumn{1}{|c|}{ Assets } & \multicolumn{1}{|c|}{ Owned House } & \multicolumn{1}{c|}{ Vehicles } & \multicolumn{1}{c|}{ Land } \\
\hline Named (Identified) & Idea Named with context & Idea Named with context & Idea Named with context \\
\hline $\begin{array}{l}\text { Defined (Conceptually } \\
\text { Structured) }\end{array}$ & $\begin{array}{l}\text { Concept, how this comes about, } \\
\text { through allotment, transfer, } \\
\text { inheritance. Part-ownership }\end{array}$ & $\begin{array}{l}\text { Concept, how this comes } \\
\text { about, through allotment, } \\
\text { transfer, inheritance. }\end{array}$ & $\begin{array}{l}\text { Concept, how this comes about, } \\
\text { through allotment, transfer, } \\
\text { inheritance. Part-ownership }\end{array}$ \\
\hline Logically Designed & $\begin{array}{l}\text { Attributes like location, size, } \\
\text { related events }\end{array}$ & $\begin{array}{l}\text { Attributes like Type, Related } \\
\text { events }\end{array}$ & $\begin{array}{l}\text { Attributes like location, size, } \\
\text { related events }\end{array}$ \\
\hline Configured & $\begin{array}{l}\text { Schema with nodes, labels, ids } \\
\text { and relationships }\end{array}$ & $\begin{array}{l}\text { Schema with nodes, labels, ids } \\
\text { and relationships }\end{array}$ & $\begin{array}{l}\text { Schema with nodes, labels, ids } \\
\text { and relationships }\end{array}$ \\
\hline Instantiated & Instantiate asset with unique ID & Instantiate asset with unique ID & Instantiate asset with unique ID \\
\hline
\end{tabular}

Table 8. Relationships and relators

\begin{tabular}{|l|l|l|l|l|}
\hline & \multicolumn{2}{|c|}{ Banking (Savings) } & & \multicolumn{2}{c|}{ Loans } \\
\hline Named (Identified) & $\begin{array}{l}\text { Name of the } \\
\text { idea and context } \\
\text { for relationship } \\
\text { (Savings account) }\end{array}$ & $\begin{array}{l}\text { Name of the idea and } \\
\text { context for relator } \\
\text { (Bank) }\end{array}$ & $\begin{array}{l}\text { Name of the idea and } \\
\text { context for relationship }\end{array}$ & $\begin{array}{l}\text { Name of the idea and } \\
\text { context for relator } \\
\text { (Housing Finance } \\
\text { Company) }\end{array}$ \\
\hline $\begin{array}{l}\text { Defined (Conceptually } \\
\text { Structured) }\end{array}$ & $\begin{array}{l}\text { Concept of } \\
\text { Relationship }\end{array}$ & $\begin{array}{l}\text { Concept of Role of } \\
\text { relator }\end{array}$ & $\begin{array}{l}\text { Concept of } \\
\text { Relationship }\end{array}$ & $\begin{array}{l}\text { Concept of Role of } \\
\text { relator, }\end{array}$ \\
\hline Logically Designed & Related Attributes & Related Attributes & Related Attributes & Related Attributes \\
\hline Configured & Network Schema & Network Schema & Network Schema & Network Schema \\
\hline Instantiated & Account No. & $\begin{array}{l}\text { Instantiate with } \\
\text { unique ID }\end{array}$ & Account No. & $\begin{array}{l}\text { Instantiate with } \\
\text { unique ID }\end{array}$ \\
\hline
\end{tabular}

Table 9. Separations that come in the way of formal credit

\begin{tabular}{|c|c|c|c|c|c|}
\hline Informational & Capability & Spatial & Temporal & Financial & Social \\
\hline $\begin{array}{l}\text { From borrower's } \\
\text { view-point } \\
\text { information on } \\
\text { processes may be } \\
\text { hard to access and } \\
\text { understand. }\end{array}$ & $\begin{array}{l}\text { Capability to } \\
\text { utilize funds may } \\
\text { not be there. For } \\
\text { example, starting } \\
\text { a small business } \\
\text { requires lot more } \\
\text { than mere access } \\
\text { to funds. }\end{array}$ & $\begin{array}{l}\text { Not all bank } \\
\text { branches lend. } \\
\text { Getting a loan } \\
\text { may need } \\
\text { multiple trips to } \\
\text { remote locations }\end{array}$ & $\begin{array}{l}\text { Banks may take } \\
\text { rather long to } \\
\text { disburse loans. } \\
\text { The people may } \\
\text { need to work with } \\
\text { Micro-finance } \\
\text { companies who } \\
\text { may charge higher. }\end{array}$ & $\begin{array}{l}\text { People may not have } \\
\text { access to collateral. } \\
\text { Only some banks } \\
\text { may accept gold as } \\
\text { collateral. If they } \\
\text { pledge land, they } \\
\text { may lose their } \\
\text { source of livelihood. }\end{array}$ & $\begin{array}{l}\text { Communities that } \\
\text { are not considered } \\
\text { as trust-worthy end } \\
\text { up getting less loans. }\end{array}$ \\
\hline
\end{tabular}


Table 10. Perspectives on metric

\begin{tabular}{|l|l|}
\hline $\begin{array}{l}\text { Perspectives } \\
\text { on Metric }\end{array}$ & Remarks \\
\hline Contextual & $\begin{array}{l}\text { This pertains to name of the metric and } \\
\text { context of the metric. For example, the } \\
\text { metric may pertain to an area or category or } \\
\text { class of people. The metrics get aggregated at } \\
\text { higher and higher levels of granularity. }\end{array}$ \\
\hline Conceptual & $\begin{array}{l}\text { This gives the idea behind any metric. } \\
\text { Typically, a metric is a ratio between two } \\
\text { measures. The metrics are defined using } \\
\text { different perspectives of Balanced Score Card: } \\
\text { Financial, Customer (Citizen, Community } \\
\text { and Business), Process (Governance and } \\
\text { Social Processes) and Learning and Growth. }\end{array}$ \\
\hline Logical & $\begin{array}{l}\text { Gives details of the schema to compute a } \\
\text { metric }\end{array}$ \\
\hline Physical & Nodes: Corresponding to the Schema \\
\hline Detailed & $\begin{array}{l}\text { Each instance of measurement is given } \\
\text { a unique number and linked to other } \\
\text { dimensions }\end{array}$ \\
\hline
\end{tabular}

Table 11 describes how a metric is reified in Tantra Framework through perspectives (should not be confused with balanced scorecard perspectives). Table 12 covers typical metrics pertaining to Governance context that can be tracked at individual level and aggregated. Table 13 covers indices aligned with Balanced Scorecard Perspectives. Tantra Framework is implemented using Neo4j graph database which gives it power of visualization.

Tantra Framework can be a great resource to Social Scientists supporting research methods such as Action Research, Ethnography, Case Study and Grounded Theory Methods (Myers, 1997). It is particularly suited to Grounded Theory Method. According to Martin and Turner (Martian \& Turner, 1986), grounded theory is "an inductive, theory discovery methodology that allows the researcher to develop a theoretical account of the general features of a topic while simultaneously grounding the account in empirical observations or data." The grounded theory suggests that there should be a continuous interplay between data collection and analysis.

Table 11. Typical metrics that can be measured for people and their description

\begin{tabular}{|l|l|l|l|l|l|}
\hline Poverty Level & Inequality & Unemployment & Productivity & Access Metric & Separation Metric \\
\hline $\begin{array}{l}\text { Number of Poor } \\
\text { who have income } \\
\text { below poverty line } \\
\text { (income level) per } \\
\text { thousand. }\end{array}$ & $\begin{array}{l}\text { Gini Index is } \\
\text { used to measure } \\
\text { inequality. }\end{array}$ & $\begin{array}{l}\text { Number of people } \\
\text { who are not employed } \\
\text { per thousand as well } \\
\text { as under-employed. }\end{array}$ & $\begin{array}{l}\text { Standard } \\
\text { measurements. }\end{array}$ & $\begin{array}{l}\text { The number of } \\
\text { people per thousand } \\
\text { in a given context } \\
\text { who have access to } \\
\text { a particular service } \\
\text { maybe through relator. }\end{array}$ & $\begin{array}{l}\text { This metric can be } \\
\text { done per thousand } \\
\text { people and } \\
\text { aggregated upwards. }\end{array}$ \\
\hline
\end{tabular}

Table 12. Operationalizing tantra framework for balanced development

\begin{tabular}{|l|l|l|}
\hline Sl. No. & Topic & Remarks \\
\hline 1. & Issues in the current system & $\begin{array}{l}\text { Poor management of resources; disparities in the pace and level } \\
\text { of development across provinces and across districts. } \\
\text { Denial of basic needs of food, water and shelter to a substantial } \\
\text { proportion of the population. } \\
\text { Lack of sensitivity, transparency and accountability in many } \\
\text { facets of the State machinery, particularly those that have an } \\
\text { interface with the public. } \\
\text { Lack of credibility - the gap between the intent and the actions - } \\
\text { of some institutions in society. } \\
\text { Inadequate application of rules, evasion of taxes and failure in } \\
\text { getting timely justice. } \\
\text { Existence of a significant number of the voiceless poor with little } \\
\text { opportunities for participating. } \\
\text { Deterioration of physical environment in the urban and rural } \\
\text { areas. }\end{array}$ \\
\hline 2. & Change Agents & $\begin{array}{l}\text { Government bodies and service providers that handle policy, } \\
\text { legal aspects, execution all the way to last mile. }\end{array}$ \\
\hline
\end{tabular}




\begin{tabular}{|c|c|c|}
\hline 3. & Desired Change & $\begin{array}{l}\text { Shelter, gainful employment for all and balanced development of } \\
\text { regions irrespective of rural, urban or remote. }\end{array}$ \\
\hline 4. & List of Services to be built using Tantra Framework & $\begin{array}{l}\text { Relevant metrics can be computed to asses the status of } \\
\text { development. }\end{array}$ \\
\hline 5. & $\begin{array}{l}\text { Strategic Alignment between Objectives and } \\
\text { services (How these services meet the objectives) }\end{array}$ & $\begin{array}{l}\text { Based on the above metrics, action plan with priorities, timelines } \\
\text { and resources required can be established. }\end{array}$ \\
\hline 6. & Design of change Process with Purpose & $\begin{array}{l}\text { Using Tantra Framework broad social data from formal } \\
\text { and informal sources is collected and this can help design } \\
\text { interventions that need to be attempted. }\end{array}$ \\
\hline 7. & Transition Process & $\begin{array}{l}\text { Current processes should give way to services that are built on } \\
\text { the framework with ability to seed and validate data about people } \\
\text { and build the eco-system that includes all stakeholders. }\end{array}$ \\
\hline 8. & $\begin{array}{l}\text { Operational aspects and organizing actors/ } \\
\text { Institutions }\end{array}$ & Existing Government organizations can be tasked as nodal org. \\
\hline 9. & Process for collecting feedback & $\begin{array}{l}\text { Feedback from all stakeholders can be collected and shared as } \\
\text { appropriate. Feedback should be used to achieve continuous } \\
\text { service improvement. }\end{array}$ \\
\hline 10. & Training Plan & $\begin{array}{l}\text { The officials and people need to be trained with online material } \\
\text { as well as off-line programs. }\end{array}$ \\
\hline 11. & Future Roadmap & $\begin{array}{l}\text { The scope of Balanced Development can be enhanced to cover } \\
\text { additional goals in line with the UN SDG goals. }\end{array}$ \\
\hline
\end{tabular}

Table 13. Skill development using theory of change process

\begin{tabular}{|c|c|}
\hline Summary Statement & $\begin{array}{l}\text { If more people are skilled unemployment can be reduced. If people have better skills then they can get } \\
\text { better jobs and augment their incomes. If employment increases poverty levels can be reduced and in } \\
\text { turn GDP growth increases. }\end{array}$ \\
\hline Problem Statement & $\begin{array}{l}\text { People are not able to get jobs as they lack skills. There are jobs which are not getting filled due to lack of } \\
\text { skills. }\end{array}$ \\
\hline Overall Goal & $\begin{array}{l}\text { The growth in GDP attributed due to higher employment levels, reduction in poverty levels and } \\
\text { reduction in inequalities. }\end{array}$ \\
\hline Change Process & $\begin{array}{l}\text { Imparting training on hands-on-skills, knowledge about the field to attain proficiency level and } \\
\text { orientation to do work professionally and ethically. }\end{array}$ \\
\hline $\begin{array}{l}\text { Change } \\
\text { Markers }\end{array}$ & $\begin{array}{l}\text { Demonstration of proficiency through some form of output.. Feedback from potential customers or } \\
\text { experts in the field as far as employability is concerned. }\end{array}$ \\
\hline Meta-Theory & Formal, holistic training can help people compared to learning on the job opportunistically. \\
\hline Inputs & Publicizing the programme. Incentive to people to attend the program. \\
\hline Actors & $\begin{array}{l}\text { End-user/Beneficiaries: Students/workers looking to upgrade skills, potential employers, industry at } \\
\text { large that needs skills; Implementing actors: Service Providers, Curriculum owners, teachers, Program } \\
\text { Owners (Skills Ministries); Spoilers: Middle-men who may be dishonest; Points of collaboration: } \\
\text { Industry association, sponsors, NGOs, other Ministries, State and District Administration. }\end{array}$ \\
\hline Domains of Change & Soft skills, Professionalism, Ethics, Culture of accomplishment, Sectoral skills \\
\hline Internal Risks & $\begin{array}{l}\text { Flooding of only one type of skills may disrupt current wage levels. Skilling with low achievement may } \\
\text { bring disrepute to agencies and employers. }\end{array}$ \\
\hline
\end{tabular}




\begin{tabular}{|l|l|}
\hline Assumptions & $\begin{array}{l}\text { People want to improve themselves; Employers are open to hire skilled workers; Employers willing to } \\
\text { pay reasonable wages; Teachers focused on delivering learning outcomes; Availability of facilities to } \\
\text { deliver training; People do not drop out from the programmes; People are committed to complete the } \\
\text { programme; People are committed to use the skills in a future job; Reasonable possibility of getting a job } \\
\text { within reasonable time of skilling; Employers will commit to address any further skill gaps. }\end{array}$ \\
\hline External Risks & $\begin{array}{l}\text { Market dynamic changing that reduces demand. This needs to be constantly monitored. The programme } \\
\text { should have variety, breadth along with specialization. Budget cuts. Careful use of allocated resources. } \\
\text { Continuous monitoring, sharing of success stories and collecting feedback from employers. Looking for } \\
\text { additional sponsorships. }\end{array}$ \\
\hline $\begin{array}{l}\text { Obstacles to } \\
\text { Success }\end{array}$ & $\begin{array}{l}\text { Any diversion of funds, corruption and performance issues of service providers, teachers and students. } \\
\text { Backup plan in each of the cases. }\end{array}$ \\
\hline $\begin{array}{l}\text { Knock-On } \\
\text { Effects }\end{array}$ & $\begin{array}{l}\text { Positive: People may move away from alcoholism. May lead to reduction in domestic violence. } \\
\text { Improvement in mental health. Negative: Other missions may have reduced allocations. }\end{array}$ \\
\hline
\end{tabular}

\section{Application of Tantra Framework for Balanced Development}

Table 14. Modeling tantra framework to facilitate balanced development

\begin{tabular}{|c|c|c|}
\hline $\begin{array}{l}\text { Sl. } \\
\text { No. }\end{array}$ & Aspect & Remarks \\
\hline 1. & People & $\begin{array}{l}\text { Here the data on access to shelter, gainful } \\
\text { employment and basic needs is checked. }\end{array}$ \\
\hline 2. & $\begin{array}{l}\text { Locations, } \\
\text { Zones }\end{array}$ & $\begin{array}{l}\text { The geographic dimension cane be } \\
\text { modeled into Zones with certain } \\
\text { characteristics such as rural, urban } \\
\text { and remote. }\end{array}$ \\
\hline 3. & Events & $\begin{array}{l}\text { Events tracked can be life-cycle } \\
\text { events for individuals as well as } \\
\text { events pertaining to processes of } \\
\text { Governance. }\end{array}$ \\
\hline 4. & Assets & Assets of citizens can be modeled here \\
\hline 5. & Process & $\begin{array}{l}\text { Intervention processes as well as } \\
\text { routine operational processes can be } \\
\text { tracked here. }\end{array}$ \\
\hline 6. & Objective & $\begin{array}{l}\% \text { Gainfully employed, \% with access } \\
\text { to shelter and other appropriate } \\
\text { metrics can be tracked here. }\end{array}$ \\
\hline 7. & Relator & $\begin{array}{l}\text { All Government Departments, } \\
\text { Employers as well as those who lease/rent } \\
\text { out houses can be considered relators. }\end{array}$ \\
\hline 8. & Relationships & $\begin{array}{l}\text { The relationships between different } \\
\text { aspects }\end{array}$ \\
\hline 9. & Separations & $\begin{array}{l}\text { The Financial, Spatial, Informational, } \\
\text { Temporal, Social and Capability } \\
\text { Separation of people are modeled here. }\end{array}$ \\
\hline
\end{tabular}

The goals of balanced development are shelter, gainful employment for all using Good Governance. Here we explain how Tantra Framework can be used to model and analyze the status of development and operationalize any changes needed. Table 14 details the high-level plan to operationalize Tantra Framework for Balanced Development. This uses ITIL change management methodology (BMC Software). Table 15, explains how an intervention such as training people for better skills can help balanced development. Skill is a great leveler especially in today's economy. Table 16 details how Tantra Framework can be modeled to facilitate Balanced Development. Table 17 contains the analysis enabled by Tantra Framework.

Table 15. Analyzing balanced development using tantra framework

\begin{tabular}{|l|l|l|}
\hline$\#$ & Aspect & Remarks \\
\hline 1. & People & $\begin{array}{l}\text { Analysis can be made as far as access } \\
\text { gaps are concerned and whether the } \\
\text { benefits of Government schemes } \\
\text { are reaching the people in a fair and } \\
\text { equitable manner. For example, who can } \\
\text { benefit with what skill can be analyzed } \\
\text { and check if existing interventions help. }\end{array}$ \\
\hline 2. & $\begin{array}{l}\text { Locations, } \\
\text { Zones }\end{array}$ & $\begin{array}{l}\text { Analysis based on relator zones, } \\
\text { backward and forward districts can be } \\
\text { done. This can be used to target the } \\
\text { interventions better. }\end{array}$ \\
\hline 3. & Events & $\begin{array}{l}\text { Events can be analyzed to understand } \\
\text { acceptance of new scheme as well as } \\
\text { timeliness of process. }\end{array}$ \\
\hline 4. & Assets & Asset ownership can be analyzed here. \\
\hline
\end{tabular}




\begin{tabular}{|l|l|l|}
\hline 5. & Process & $\begin{array}{l}\text { Analysis may be made on blockers to } \\
\text { implementing Government Schemes } \\
\text { on. Fairness in getting access to job } \\
\text { opportunity can be tracked to see if any } \\
\text { specific groups of people get excluded. }\end{array}$ \\
\hline 6. & Objective & $\begin{array}{l}\text { Objectives at various levels can be } \\
\text { analyzed to assess the effectiveness of } \\
\text { the changed process. Effectiveness of } \\
\text { targeting and impact on the overall } \\
\text { economy can be analyzed. }\end{array}$ \\
\hline 7. & Relator & $\begin{array}{l}\text { Analysis of how well relators perform. } \\
\text { This includes Government Offices, } \\
\text { officials, online portals, process } \\
\text { documents and so on. }\end{array}$ \\
\hline 8. & Relationships & $\begin{array}{l}\text { Every new 'fact" can be stored as } \\
\text { relationships among different aspects. } \\
\text { Each relationship in turn may make } \\
\text { use of other relationships. }\end{array}$ \\
\hline 9. & Separations & $\begin{array}{l}\text { All the different separations - spatial, } \\
\text { temporal, financial, informational and } \\
\text { capability can be analyzed that come } \\
\text { in the way of Balanced Development. } \\
\text { Some plans may need to be crafted } \\
\text { for specific areas and geographies or } \\
\text { sections of people. }\end{array}$ \\
\hline
\end{tabular}

\section{Discussions}

Tantra Framework needs to have a process to get the information from concerned departments as well as people periodically and on demand. To facilitate collection of information periodically, Know-yourCitizen process should be unveiled where each citizen provides information about him to Government annually, with option to update if need be. Tantra Information Framework should evolve into Tantra Digital Governance Framework where multiple institutions participate

\begin{tabular}{|l|l|l|}
\hline $\begin{array}{l}\text { Laws, } \\
\text { Policies, } \\
\text { Processes }\end{array}$ & $\begin{array}{l}\text { Architecture and } \\
\text { Governance } \\
\text { Guidelines }\end{array}$ \\
\hline $\begin{array}{l}\text { Information } \\
\text { Champions }\end{array}$ & $\begin{array}{l}\text { Integration Layer } \\
\text { (Guidelines and } \\
\text { Tools) }\end{array}$ \\
\hline $\begin{array}{l}\text { Application Layer } \\
\text { (Scenarios and Cases) }\end{array}$ \\
\hline $\begin{array}{l}\text { Applications } \\
\text { Tantra Information } \\
\text { Framework }\end{array}$ \\
\hline
\end{tabular}

Figure 4. Tantra digital governance framework. through information champions/agents. Figure 3 is modeled after TM Forum's Frameworx (TM Forum).

\section{Conclusions}

Many decades ago Zachman suggested that IT systems needed to be architected by keeping the whole Enterprise in mind, as Enterprises outlive IT systems. We have applied the same line of thinking at the level of society and have proposed highly generic Tantra framework that can manage the entire information pertaining to society in one place. In this paper, we have looked at using Tantra Framework to realize balanced development of Economy in Indian context. There are opportunities to apply Tantra Framework to validate other development theories such as Balanced Growth.

\section{References}

Bartels, Robert (1968). The General Theory of Marketing, The General of Marketing, Journal of Marketing, 32(1): 29-33. https://www.jstor.org/stable/1249193.

BMC Software, How to embrace ITIL as an organization, https:// youtu.be/jkrQWDOGf.

Easley, David and Kleinberg, Jon (2010) Networks, Crowds, and Markets: Reasoning About a Highly Connected World. Cambridge University Press; 2000. https://www.cs.cornell. edu/home/kleinber/networks-book/.

Kaplan, Robert S. (2010). Conceptual Foundations of the Balanced Scorecard, Working Paper. https://www.hbs. edu/faculty/Publication\%20Files/10-074_0bf3c151-f82b4592-b885-cdde7f5d97a6.pdf.

Khan, Faheem Jehangir (2008). Balanced Development, Working Paper. https://www.researchgate.net/publication/315791425.

Martian, Patricia Yancey and Turner, Barry A. (1986), Grounded Theory and Organizational Research. The Journal of Applied Behavioral Science, 22(2). https://doi. org/10.1177/002188638602200207.

Myers, Michael David (June1997). Qualitative research in information systems. MIS Quarterly, 22(2). https://doi. org/10.2307/249422.

Rik Maes (1999). A Generic Framework for Information Management. Primavera Working Paper, 99-03, Universiteit van Amsterdam. https://www.researchgate. net/publication/242321998_A_Generic_Framework_for_ Information_Management.

Santos Jr, Paulo et. al. (2013). An ontology-based analysis and semantics for organizational structure modelling in the 
ARIS method. Information Systems Journal, 38(5):690-708. DOI: 10.1016/j.is.2012.09.004.

Tarafdar, Monideepa and Singh, Ramendra (December 2011). A Market Separations Perspective to Analyze the Role of ICT in Development at the Bottom of the Pyramid (ROP). 4th Annual SIG Globdev Workshop, Association for Information Systems, Shanghai, China. http://www. research.lancs.ac.uk/portal/en/publications/a-marketseparations-perspective-to-analyze-the-role-of-ict-in-development-at-the-bottom-of-the-pyramid-rop(28a46534089d-416e-baa6-006f645eeafd).html.

TM Forum, Frameworx. https://www.tmforum.org/tm-forum-frameworx-2.

Weiss (1995). Nothing as Practical as Good Theory: Exploring Theory-Based Evaluation for Comprehensive Community Initiatives for Children and Families. In:
New Approaches to Evaluating Community Initiatives, Concepts, Methods, and Contexts, Edited by Connel, Kubisch and Scorr. ISBN 0-89843-167-O. https://www.scribd.com/ document/150652416/Nothing-as-Practical-as-aGood-Theory-Exploring-Theory-Based-Evaluation-forComprehensive-Community-Initiatives-for-Childrenand-Families.

Zachman, John A (2003). Zachman Framework, A Primer for Enterprise Engineering and Manufacturing. http://www. zachmaninternational.com.

Zachman, John A (2007). The Framework for Enterprise Architecture: Background, Description and Utility. https:// www.zachman.com/resources/ea-articles-reference/ 327-the-framework-for-enterprise-architecture-background-description-and-utility-by-john-a-zachman. 